\title{
Makna Simbol “ZERO” Sebagai Pesan Non Verbal Yayasan Matahati Dalam Mencegah Penyebaran HIV Aids Di Kawasan Pangandaran
}

\author{
Ditha Prasanti, Hadi Suprapto Arifin, Ikhsan Fuady \\ Program Studi Ilmu Komunikasi, Fakultas Ilmu Komunikasi Universitas Padjadjaran \\ Jl.Raya Jatinangor - Sumedang KM.21 Bandung \\ dithaprasanti@gmail.com, hsadalong85@gmail.com, sandyca@yahoo.co.id
}

Masuk tanggal : 23-06-2019, revisi tanggal : 29-12-2019, diterima untuk diterbitkan tanggal : 03-01-2020

\begin{abstract}
This article is the result of a study of health communication studies on HIV AIDS prevention and prevention by the Matahati Foundation in Pangandaran district. Like the iceberg phenomenon, the number of HIV AIDS in Pangandaran district is increasing, so that it attracts the attention of various parties, one of which is the Matahati Foundation. In this article, the method which used is qualitaitv method, in line with the aim of research that is describes the existence of a symbol used by the Matahati Foundation, namely the symbol "ZERO". If examined in communication studies, this ZERO symbol has a certain meaning in relation to the vision and mission of the Matahati Foundation itself. This was later revealed by the author in the discussion section of this article. The results showed that the symbol "ZERO" for the Matahati Foundation had several meanings, including: as a non-verbal message containing the meaning of the hopes of the Matahati Foundation in reducing the prevalence of HIV AIDS rates in Pangandaran district; the meaning of motivation for people with HIV AIDS to try to arrive at "ZERO" HIV AIDS, which means recovery; and the meaning of persuasion for the community to be together in order to achieve "ZERO" HIV AIDS in Pangandaran district.
\end{abstract}

Keywords: HIV AIDS, meanings, non verbal, symbols, ZERO

\begin{abstract}
Abstrak
Artikel ini merupakan hasil penelitian kajian komunikasi kesehatan tentang pencegahan dan penanggulangan HIV AIDS yang dilakukan Yayasan Matahati di kabupaten Pangandaran. Layaknya fenomena gunung es, angka HIV AIDS di kabupaten Pangandaran semakin meningkat, sehingga menarik perhatian berbagai pihak, salah satunya adalah Yayasan Matahati. Dalam artikel ini, metode penelitian yang relevan digunakan adalah metode kualitatif, sebagaimana tujuan dari penelitian ini yaitu menggambarkan tentang adanya sebuah simbol yang digunakan oleh Yayasan Matahati, yaitu simbol "ZERO". Jika diteliti dalam kajian komunikasi, simbol ZERO ini memiliki makna tertentu kaitannya dengan visi misi dari Yayasan Matahati sendiri. Hal tersebut yang kemudian diungkapkan penulis dalam bagian pembahasan artikel ini. Hasil penelitian menunjukkan bahwa simbol "ZERO" bagi Yayasan Matahati tersebut memiliki beberapa makna, di antaranya: sebagai pesan non verbal yang berisi makna harapan Yayasan Matahati dalam menurunkan prevalensi angka HIV AIDS di kabupaten Pangandaran; makna motivasi bagi para penyandang HIV AIDS agar berupaya untuk sampai pada "ZERO" HIV AIDS, yang berarti sembuh; dan makna persuasi bagi
\end{abstract}


masyarakat untuk bersama-sama dalam rangka mencapai "ZERO" HIV AIDS di kabupaten Pangandaran.

Kata Kunci: HIV AIDS, non verbal, makna, simbol, ZERO

\section{Pendahuluan}

Yayasan Matahati, sebagai salah satu komunitas penggiat yang peduli HIV AIDS, hadir di kawasan Pangandaran, untuk mencegah dan menanggulangi prevalensi angka HIV AIDS di kawasan tersebut. Itulah prolog yang sempat disampaikan Agus, selaku ketua Yayasan Matahati. Tak dapat dipungkiri, beberapa informasi tentang angka HIV AIDS inipun terus meningkat, layaknya fenomena gunung es di kabupaten Pangandaran. Artikel ini merupakan hasil penelitian kajian komunikasi kesehatan tentang pencegahan dan penanggulangan HIV AIDS yang dilakukan Yayasan Matahati di kabupaten Pangandaran.

Sebagaimana diungkapkan juga oleh Agus, ketua Yayasan Matahati kepada surat kabar lokal di Pangandaran tentang angka HIV AIDS yang seperti fenomena gunung es tersebut. Apabila terdapat 72 penderita HIV/AIDS, kalau memakai rumus WHO yang dikalikan 100, berarti jumlahnya sebanyak 72.000 orang. Menurut Agus bahwa jumlah pengidap HIV AIDS yang teridentifikasi adalah 7.128 orang. Jumlah tersebut merupakan angka yang berpotensi tertular. Pada kenyataannya, ada yang telah tertular, tetapi belum terdeteksi, begitulah realitas di lapangan yang bisa terjadi dari angka HIV AIDS yang ada (Enceng, 2018).

HIV merupakan singkatan dari Human Immunodeficiency Virus yang menyebabkan penyakit AIDS (Acquired Immune Deficiency Syndrome). HIV secara drastis dapat menurunkan sistem kekebalan tubuh, sehingga memungkinkan penyakit, bakteri, virus, dan infeksi lainnya menyerang tubuh. Sebagaimana penulis temukan dalam beberapa pemberitaan media massa tentang merebaknya angka HIV AIDS di Pangandaran, Den (2018) menyampaikan bahwa Yayasan Matahati yang bergerak di bidang pencegahan HIV AIDS terus mendorong DPRD Kabupaten Pangandaran merancang Peraturan Daerah (Perda) HIV AIDS. Bahkan Ketua Yayasan Matahati sendiri yaitu Agus Abdulah, telah melakukan audiensi dengan Komisi I DPRD Kabupaten Pangandaran, dengan harapan perda penanggulangan HIV/AIDs bisa terwujud (Den, 2018).

Dalam pemberitaan lainnya, mengungkapkan bahwa ketua Yayasan Matahati, menegaskan kasus HIV/AIDS di Pangandaran terus mengalami peningkatan. Bahkan masuk di populasi rendah, yaitu bagi ibu rumah tangga dan anak-anak. Fakta lainnya menunjukkan bahwa kasus tersebut hampir ada di seluruh kecamatan yang ada di Pangandaran. Hal tersebut yang kemudian mendorong Pemkab Pangandaran untuk segera menerbitkan Perda penanggulangan dan penanganan HIV/AIDS (Madlani, 2018).

Proses penerbitan Perda penanggulangan HIV AIDS tersebut juga telah penulis sampaikan dalam artikel berjudul Komunikasi Sosial dalam Mendorong Kebijakan Publik HIV AIDS di Pangandaran. Arifin, Prasanti, dan Fuady (2018) mengungkapkan adanya proses komunikasi sosial yang dilakukan berbagai pihak, 
Ditha Prasanti, Hadi Suprapto Arifin, Ikhsan Fuady: Makna Simbol “ZERO” Sebagai Pesan Non Verbal Yayasan Matahati Dalam Mencegah Penyebaran HIV Aids Di Kawasan Pangandaran

termasuk di dalamnya adalah yayasan Matahati, dalam mendorong Pemkab Pangandaran untuk menetapkan Perda penanggulangan dan pencegahan HIV AIDS (Arifin, H. S., Prasanti, D., \& Fuady, 2018)

Selain itu, penelitian tentang HIV AIDS ini juga tentu bukan satu-satunya yang dilakukan di Indonesia. Salah satunya, penulis menemukan data tentang tingginya kasus HIV AIDS di Yogyakarta menuntut pihak berwenang melakukan tindakan yang tepat agar penyebaran virus ini dapat diminimalisir. Mahendra \& Sugiantoro (2018) mengungkapkan bahwa manajemen pelayanan publik yang diterapkan di KPA Kota Yogyakarta lebih bersifat koordinatif dan pelayanan tidak langsung. Hal yang dilakukan berupa memaksimalkan peran OPD, LSM, dan masyarakat guna menjangkau kelompok masyarakat yang rentan terinfeksi virus HIV AIDS. Tindakan tersebut dinilai efektif karena adanya koordinasi antar lembaga, sehingga mampu mengidentifikasi penderita HIV dari tahap awal sampai pada tahap pelayaan lanjutan yang tepat (Mahendra, G. K., \& Sugiantoro, 2018).

Jika penulis melihat data di atas, meskipun berlokasi di Indonesia, tetapi ada perbedaan yang signifikan dengan penelitian yang telah dilakukan di Pangandaran ini. Hal tersebut juga menjadikan penelitian ini memiliki tingkat urgensitas yang tinggi karena melihat dari berbagai data yang menunjukkan prevalensi angka HIV AIDS mulai mendekati populasi rendah di Pangandaran, yaitu ibu rumah tangga dan anak-anak. Apalagi mengingat bahwa belum ada yang mengungkapkan penelitian tentang pencegahan dan penanggulangan HIV AIDS di Pangandaran. Tetapi dalam artikel ini, penulis focus bertujuan untuk mengangkat tentang yayasan Matahati sebagai komunitas penggiat anti HIV AIDS yang tergerak untuk mencegah dan menanggulangi prevalensi angka HIV AIDS di Pangandaran.

Dalam penelitian yang lain, penulis menemukan beberapa literatur sejenis tentang HIV AIDS. Nzioka (2000) misalnya, mengungkapkan tentang kematian akibat HIV / AIDS yang semakin umum terjadi di Kenya. Namun, cara-cara di mana orang yang didiagnosis dengan HIV / AIDS dan masyarakat secara umum lebih memahami jenis kematian ini telah sedikit diselidiki. Dengan menganalisis akun dari sampel empat belas orang heteroseksual yang didiagnosis HIV positif dan disajikan untuk perawatan di empat klinik khusus di Nairobi, dan akun lain yang diperoleh dari anggota ulama dan umat awam, Nzioka (2000) meneliti bagaimana orang memahami kematian karena HIV / AIDS. Terinfeksi oleh HIV, sama dengan kematian, dan karena AIDS bertindak sebagai metafora jika terkontaminasi moral dan fisik, infeksi HIV memberikan citra dan identitas negatif pada individu tersebut. Citra dan identitas ini diproyeksikan ke dalam kehidupan di luar kematian fisik. Jenis kematian ini memiliki implikasi pada cara orang yang hidup dengan HIV / AIDS mencari pengobatan dan mengelola status seropositif HIV. Hal ini juga relevan dengan pemahaman tentang cara di mana pemakaman dan penguburan untuk orang yang meninggal karena HIV / AIDS sekarang sedang diselenggarakan di Kenya (Nzioka, 2000).

Data lain tentang HIV AIDS juga diungkapkan oleh Iqbal dan Zorn (2010). Menurutnya, konflik kekerasan bertindak sebagai kontributor utama untuk penularan human immunodeficiency virus (HIV). Namun hingga saat ini belum 
ada pemeriksaan empiris hubungan konflik-HIV yang dilakukan. Berfokus pada ilmu politik dan kesehatan masyarakat, mereka menetapkan kerangka teoritis untuk memahami hubungan potensial ini dan melanjutkan untuk menyajikan data tentang penyebaran spatio-temporal HIV AIDS di 43 negara Afrika selama periode 1997-2005. Iqbal dan Zorn kemudian menilai hubungan antara konflik domestik dan internasional dan tingkat infeksi HIV AIDS sambil mengendalikan sejumlah faktor berpengaruh lainnya. Analisis kami mendukung hubungan positif yang jelas antara konflik internasional dan domestik dan peningkatan prevalensi HIV / AIDS, serta efek paliatif yang signifikan untuk pendidikan dan pengembangan ekonomi pada kejadian HIV / AIDS (Iqbal, Z., \& Zorn, 2010).

Mengingat tingginya nilai urgensitas isu HIV AIDS, penulis juga menemukan penelitian lainnya tentang HIV AIDS dalam bidang ilmu eksakta yang berbeda denga penulis. Penelitian ini disampaikan juga oleh Mukandavire dkk (2009) tentang model HIV AIDS dalam penularan seksual dengan periode inkubasi eksplisit yang diusulkan sebagai sistem persamaan diferensial waktu tunda diskrit. Ambang batas dan kesetimbangan untuk model ditentukan dan stabilitas diperiksa. Analisis kualitatif model juga disajikan. Mereka menggunakan model ini untuk mempelajari dampak kampanye pendidikan kesehatan masyarakat terhadap penyebaran HIV AIDS sebagai pendekatan strategi tunggal dalam pencegahan HIV. Reproduksi dasar yang diinduksi oleh pendidikan untuk model ini dibandingkan dengan angka reproduksi dasar (R0) untuk HIV AIDS tanpa adanya intervensi untuk menilai kemungkinan manfaat masyarakat dari kampanye pendidikan kesehatan masyarakat. Kesimpulan penelitiannya bahwa dalam pengaturan di mana kampanye pendidikan kesehatan publik HIV AIDS efektif dan dengan jumlah rata-rata yang wajar dari pasangan yang terinfeksi HIV, kampanye pendidikan kesehatan masyarakat dapat memperlambat epidemi dan lebih efektif ketika diberikan kepada keduanya yang belum dewasa secara seksual (remaja pra dan awal) dan individu dewasa secara seksual (dewasa) secara bersamaan (Mukandavire, Z., Garira, W., \& Tchuenche, 2009).

Mulai dari penelitian tentang gambaran fenomena HIV AIDS di Afrika sampai dengan model kampanye kesehatan dalam pencegahan HIV AIDS, maka penulis dapat memfokuskan tulisan ini dari sudut pandang yang unik lainnya. Dikatakan unik karena yayasan Matahati memang memiliki cara unik dalam melakukan pencegahan HIV AIDS di Pangandaran. Merujuk pada beberapa literatur ilmiah di atas, penulis melihat adanya nilai orisinalitas dalam penelitian yang diungkapkan penulis ini, yaitu keberadaan salah satu pihak yang peduli dalam pencegahan dan penanggulangan HIV AIDS di Pangandaran, yaitu yayasan Matahati.

Pentingnya kajian tentang makna yang dirasakan informan penelitian juga dibahas oleh Ariadne (2017). Selain itu, informan juga memaknai pencalonan dari jalur perseorangan maupun dari jalur partai bukanlah faktor yang signifikan bagi mereka dalam menentukan pilihan. Informan memandang bahwa faktor utama penentu layak atau tidaknya seseorang dipilih menjadi kepala daerah adalah karakter, prestasi dan pendekatannya terhadap masyarakat, bukan dari soal dari jalur pencalonan mana dia berasal (Ariadne, 2017). Tetapi berbeda jauh dengan 
Ditha Prasanti, Hadi Suprapto Arifin, Ikhsan Fuady: Makna Simbol “ZERO” Sebagai Pesan Non Verbal Yayasan Matahati Dalam Mencegah Penyebaran HIV Aids Di Kawasan Pangandaran

fokus penelitian yang diangkat penulis disini, yaitu pemaknaan simbol ZERO bagi anggota komunitas Yayasan Matahati, sebagai komunitas penggiat anti HIV AIDS.

Dalam artikel ini, penulis menggambarkan tentang adanya sebuah simbol yang digunakan oleh Yayasan Matahati, yaitu simbol "ZERO”. Simbol tersebut terlihat dalam pesan non verbal berupa isyarat tangan dengan cara melingkarkan jempol dan telunjuk sehingga membentuk simbol "nol" atau "ZERO”. Hal inilah yang diungkapkan penulis dalam artikel ini. Jika diteliti dalam kajian komunikasi, simbol ZERO ini memiliki makna tertentu kaitannya dengan visi misi dari Yayasan Matahati sendiri. Hal tersebut yang kemudian diungkapkan penulis dalam bagian pembahasan artikel ini.

\section{Metode Penelitian}

Pendekatan penelitian yang digunakan dalam penelitian ini adalah penelitian kualitatif. Definisi dari metode penelitian, sebagaimana diungkapkan oleh Mulyana (2008), bahwa metodologi sebagai sebuah proses, prinsip, dan prosedur yang digunakan untuk mendekati problem dan mencari jawabannya" (Mulyana, 2008). Sedangkan menurut Sugiyono, metode penelitian kualitatif merupakan suatu penelitian yang digunakan untuk meneliti pada objek alamiah dimana peneliti adalah sebagai instrumen kunci, teknik pengumpulan data dilakukan secara gabungan, analisis data bersifat induktif, dan hasil penelitian kualitatif lebih menekankan makna daripada generalisasi (Sugiyono, 2012).

Oleh karena itu, dalam penelitian ini, penulis mendeskripsikan hasil penelitian sesuai dengan tujuan penelitian sendiri, yaitu mengungkapkan makna yang terkandung dari simbol "ZERO" sebagai pesan non verbal oleh Yayasan Matahati. Adapun teknik pengumpulan data dalam penelitian kualitatif adalah dengan melakukan observasi, wawancara mendalam, dan studi dokumentasi.

1) Observasi, teknik ini dilakukan dengan cara obervasi partisipasi aktif, yaitu penulis mengamati secara langsung berbagai kegiatan yang dilakukan informan, bahkan bekerjasama dalam kajian riset tentang kampanye pencegahan dan penanggulangan HIV AIDS di Pangandaran.

2) Wawancara, teknik ini dilakukan dengan memilih beberapa informan yang sesuai dengan kriteria penelitian atau kebutuhan penelitian yang ada, misalnya dalam artikel ini, penulis memfokuskan pada yayasan Matahati.

3) Studi dokumentasi, teknik ini dilakukan dengan cara melakukan kajian literatur penelitian jurnal nasional dan internasional yang relevan dengan kriteria penelitian penulis.

Adapun teknik analisis data yang dilakukan dalam menindaklanjuti penelitian ini adalah melalui proses trianggulasi sumber. Dalam hal ini, penulis melakukan trianggulasi sumber kepada ketua yayasan Matahati dan pihak kader yang terlibat aktif, setelah memperoleh data di lapangan dari keduanya. Penulis mengecek kembali data yang diperoleh kepada para informan tersebut. 


\section{Informan Penelitian}

Dalam penelitian ini, penulis menggunakan teknik sampling purposive, yakni memilih informan sesuai dengan kebutuhan peneliti. Jadi, penulis mengambil 4 orang informan yang terlibat dalam yayasan Matahati, yaitu: (1) Ags, ketua Yayasan Matahati; (2) Iwn, anggota Yayasan Matahati; (3) Asp, anggota Yayasan Matahati; (4) Dn, kader Yayasan Matahati.

\section{Hasil Penemuan Dan Diskusi}

Berbicara tentang makna pesan non verbal, tentu ada beberapa hal yang bersinggungan dengan konteks tersebut, misalnya jenis-jenis pesan non verbal, meliputi ekspresi wajah, gerakan mata, sentuhan, penampilan, isyarat tangan, dan lainnya. Dalam hal ini, penulis menemukan salah satu contoh hasil penelitian yang dilakukan pada tahun 1998 tentang tato bagi HIV AIDS. Brouwer (1998) yang mengungkapkan hasil penelitiannya tentang pengungkapan status seseorang yang terindikasi positif HIV melalui pesan non verbal tato. Untuk individu yang terindikasi seropositif HIV, keberadaan sehari-harinya ditandai dengan strategi penyembunyian dan pengungkapan tentang seropositifitas mereka. Beberapa individu seropositif telah memilih untuk mengungkapkan status mereka dengan cara non-verbal, daripada verbal, melalui akuisisi tato HIV / AIDS. Tanda-tanda tak terhapuskan tato ini menempel pada kulit - membuat tubuh menjadi tekstual dengan memberikan permukaan komunikatif kulit tentang status interior (seropositif) darah, jaringan, dan organ. Pemakai tato asimptomatik membuat yang tak terlihat menjadi terlihat. Fenomena ini genting secara politis, berfungsi secara kritis untuk meragukan asumsi tentang ruang dan penampilan kesehatan sekaligus meningkatkan momok pengawasan yang represif atau keras (Brouwer, 1998).

Berbeda dengan kajian Brouwer (1998) di atas yang membahas tentang tato bagi individu yang terindikasi HIV AIDS, penulis bermaksud menjelaskan bahwa disitulah pentingnya arti sebuah makna, yaitu ketika Brouwer (1998) mencari makna tato bagi individu yang terindikasi HIV AIDS. Sedangkan fokus penulis terletak pada komunitas penggiat anti HIV AIDS yang menggunakan simbol pesan non verbal berupa simbol "ZERO". Sebagai komunitas penggiat anti HIV AIDS, yayasan Matahati berupaya melakukan berbagai kegiatan dalam rangka menurunkan prevalensi angka HIV AIDS di kabupaten Pangandaran. Hal tersebut adalah upaya pencegahan dan penanggulangan HIV AIDS yang dilakukan sebagai bentuk kepedulian yayasan Matahati terhadap fenomena HIV AIDS yang terjadi.

Hal yang menarik penulis dalam kajian ini adalah keterlibatan yayasan Matahati yang ditunjukkan melalui berbagai program kerja dan kegiatannya, salah satunya adalah penggunaan simbol "ZERO" yang selalu didengungkan oleh yayasan Matahati. Disadari ataupun tidak, dalam kajian komunikasi, simbol "ZERO" tersebut mengandung pesan non verbal yang ingin disampaikan oleh Yayasan Matahati kepada khalayak, siapapun itu, terutama berkaitan dengan pencegahan dan penanggulangan HIV AIDS. 


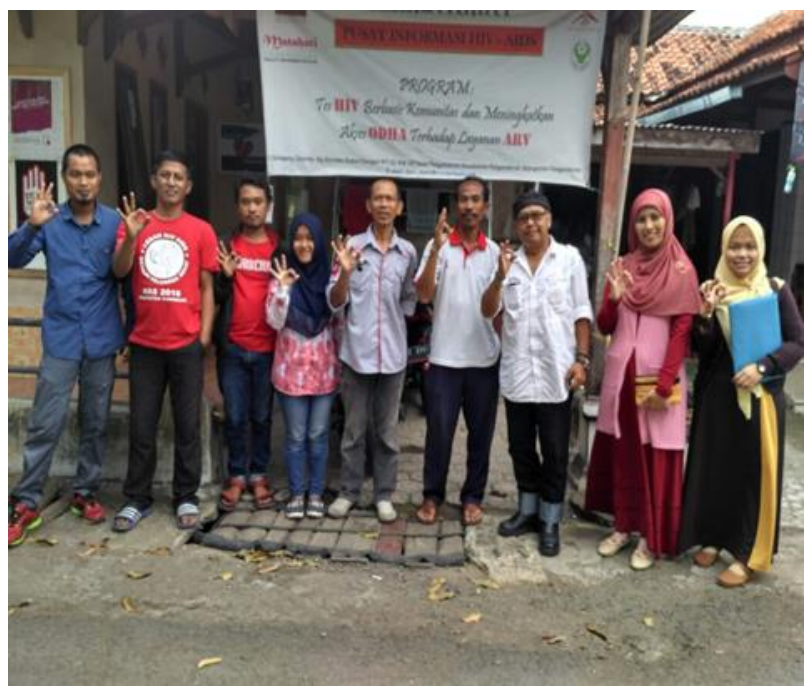

Gambar 1: Simbol “ZERO”

Gambar di atas merupakan contoh simbol "ZERO” yang dimaksud penulis, sehingga penulispun tertarik untuk membongkar makna yang terkandung dari simbol "ZERO" tersebut. Hasil penelitian menunjukkan bahwa simbol "ZERO” bagi Yayasan Matahati tersebut memiliki beberapa makna, di antaranya: sebagai pesan non verbal yang berisi makna harapan Yayasan Matahati dalam menurunkan prevalensi angka HIV AIDS di kabupaten Pangandaran; makna motivasi bagi para penyandang HIV AIDS agar berupaya untuk sampai pada "ZERO” HIV AIDS, yang berarti sembuh; dan makna persuasi bagi masyarakat untuk bersama-sama dalam rangka mencapai "ZERO" HIV AIDS di kabupaten Pangandaran.

Berdasarkan hasil observasi yang dilakukan, penulis mengamati bahwa penggunaan simbol ZERO tersebut digunakan pada saat proses sosialisasi pencegahan HIV AIDS bagi masyarakat, khususnya ibu-ibu. Kegiatan tersebut biasanya bekerja sama dengan pihak Dinas Kesehatan dan Puskesmas di Pangandaran, sehingga informasi tentang pencegahan HIV AIDS pun dapat tersampaikan.

\section{Simbol "ZERO": Makna Harapan Yayasan Matahati}

"Hati saya terpanggil untuk mencegah penyebaran HIV AIDS di sini, gimana caranya agar prevalensi angka HIV AIDS nya bisa menurun. Jadi saya bersama tim anggota yang lain menyusun berbagai rangkaian kegiatan dan project untuk mendekati orang-orang yang positif HIV, ya kalau bicara soal cerita, ada banyak lah cerita tentang ini, hemm...mulai dari gimana perjuangan ngedeketin orang-orang yang positif HIV, jalin kerjasama dengan pemkab, ketemu dinkes, puskesmas, sampai akhirnya kami inisiatif juga ngebentuk kader untuk memudahkan koordinasi. Nah, salah satunya ya harapan kami adalah bisa sampai ZERO. Ya kedengerannya mungkin gimana, tapi itu harapan ya, insyaallah diawali dengan niat positif." (Wawancara Ags, Juni 2018) 
"Kalau bicara tentang simbol mah, yaa kami punya moto, ZERO AIDS, karena itu tuh kayak harapan kami gitu, pokonya buat kami, kami pengen ngebantu gimana caranya supaya di kawasan ini bisa sampe mencapai ZERO AIDS (sambil menunjukkan simbol tangannya)" (Wawancara Iwn, Juni 2018)

Kedua kutipan wawancara di atas menunjukkan adanya makna pesan non verbal yang terkandung dari simbol " $Z E R O$ ", yang memang digunakan Yayasan Matahati dalam mengkampanyekan pencegahan dan penanggulangan HIV AIDS di Pangandaran. Makna yang pertama disampaikan adalah adanya makna harapan bagi Yayasan Matahati. Harapan disini berarti mereka ingin mencapai sampai pada angka " $Z E R O$ ” HIV AIDS.

Makna harapan bagi yayasan Matahati tentu menjadi semangat yang luar biasa yang menyebabkan mereka menjadi antusias dalam membantu pencegahan dan penanggulangan HIV AIDS. Sebagaimana disampaikan dalam kutipan wawancara di atas, makna harapan ini juga yang kemudian membuat Ags berani menyusun berbagai macam program kerja di kabupaten Pangandaran. Selain itu, Ags juga menyampaikan bahwa mereka menyusun rencana dalam rangka menjalin kerjasama dengan berbagai Dinas terkait, mulai dari Pemkab Pangandaran, Dinas Kesehatan, Puskesmas, dan pihak terkait lainnya, agar sal ing mendukung untuk mencegah dan menanggulangi terjangkitnya HIV AIDS.

\section{Simbol "ZERO": Makna motivasi untuk para penyandang HIV AIDS}

"Yah selain itu, dengan simbol "ZERO" ini tentu maksudnya memotivasi para penyandang HIV AIDS, supaya mau bangkit dari keterpurukan, seenggaknya mereka punya motivasi mau berobat, mau hidup, dan mau sembuh, karena pada awalnya ya pada sedih, ngerasa gak berguna, ya pokoknya sedih deh, hmmm sampai akhirnya ya kami bikin semacam komunitas mereka, tujuannya ya supaya saling memotivasi gitu, alhamdulilah terwujud, mereka bisa saling memotivasi, malahan ada juga yang berani membuka diri, mau cerita ke publik gitu, ada juga yang sampai jadi kader akhirnya." (Wawancara Asp, Juni 2018)

"Ya gak mudah awalnya mah, tapi kami juga gak putus asa, ya terus melakukan pendekatan sama pengidap HIV AIDS itu supaya mereka mau bangkit, jadi punya motivasi pengen sembuh. Jadi kami datang ke rumah mereka, nganter berobat, ngurusin bpjs, ke puskesmas, dan lain-lain, ya motivasi supaya mereka juga mau minum obat-obatannya.” (Wawancara Iwn, Juni 2018)

Simbol "ZERO" yang kedua ini bermakna motivasi sembuh yang ditujukan untuk para penyandang HIV AIDS. Makna motivasi ini diusung agar para penyandang HIV AIDS semangat dan berupaya untuk sampai pada "ZERO" HIV AIDS, yang berarti sembuh. Jika diamati dari kutipan wawancara di atas, penulis melihat bahwa makna yang terkandung berikutnya dari simbol "ZERO" ini adalah memotivasi para penyandang HIV AIDS agar bersemangat dalam pengobatan penyakitnya.

Memiliki semangat untuk hidup itu bukanlah hal yang mudah bagi para penyandang HIV AIDS, khususnya ketika pertama kali mereka mengetahui kondisi penyakit yang dideritanya. Ada pasien yang menjadi down, mengurung diri, tidak mau bertemu dengan orang lain, sehingga yayasan Matahati-pun 
Ditha Prasanti, Hadi Suprapto Arifin, Ikhsan Fuady: Makna Simbol “ZERO” Sebagai Pesan Non Verbal Yayasan Matahati Dalam Mencegah Penyebaran HIV Aids Di Kawasan Pangandaran

berinisiatif membentuk komunitas agar para penyandang HIV AIDS saling memotivasi satu sama lain, memberikan semangat hidup dan bangkit sampai sembuh.

\section{Simbol "ZERO": Makna persuasi untuk masyarakat}

"Ya maksudnya ngajak masyarakat juga supaya gak punya stigma negatif pada orang-orang di sekitar kita yang terkena HIV, kan sampai saat ini masih susah ya, pokonya stigma negatif itu masih ada aja, yang bikin penyandang HIV tuh jadi down, gak semangat, malu ketemu orang juga, gak mau keluar rumah, dan masih banyak lagi lah. Kami gak mau juga mereka begitu terus, akhirnya ya kami membentuk kader itu juga salah satunya ya menyampaikan pesan ke masyarakat tentang ini, ngajak gitu, supaya gak punya stigma negatif." (Wawancara Ags, Juni 2018)

"Stigma itu teh masih melekat di masyarakat sampe sekarang juga, jadi harus rutin gitu ya pokonya diajakin ikut penyuluhan, supaya makin sadar, terus mau ikut pemeriksaan juga, kan mencegah lebih baik dari mengobati, jadi ya dibujuk, walau rata-rata jadinya teh pada takut gitu, tapi ya terus dicoba, kerjasama juga sama puskesmas, kader lain, dan dinkes juga." (Wawancara Dn, Juni 2018)

Simbol "ZERO" yang ketiga bermakna persuasi, yang ditujukan untuk kalangan masyarakat luas. Makna persuasi ini berarti untuk bersama-sama dalam rangka mencapai "ZERO" HIV AIDS di kabupaten Pangandaran. Makna yang ketiga ini merupakan makna persuasi yang ditujukan kepada masyarakat luas. Dengan simbol " $Z E R O$ ” yang selalu diusung oleh Yayasan Matahati, mereka pun menyampaikan pesan agar masyarakat tidak memiliki stigma negatif terhadap para penyandang HIV AIDS. Sebaliknya, Ags dan tim lainnya menyampaikan agar masyarakat merangkul dan menyemangati para penyandang HIV AIDS untuk melakukan pengobatan terhadap penyakitnya tersebut, sampai akhirnya harapan pun tercapai, yaitu "ZERO” HIV AIDS.

\section{Simpulan}

Artikel ini merupakan hasil penelitian tentang makna pesan non verbal dalam simbol "ZERO" yang diusung oleh Yayasan Matahati di kabupaten Pangandaran. Simbol " $Z E R O$ " tersebut digunakan dalam rangka mencegah dan menanggulangi penyebaran HIV AIDS. Penelitian ini menggunakan pendekatan kualitatif, penulis melakukan pemaknaan tentang simbol " $Z E R O$ " yang digunakan Yayasan Matahati. Teknik pengumpulan data yang dilakukan adalah observasi aktif, wawancara mendalam, dan studi literatur. Hasil penelitian menunjukkan bahwa simbol "ZERO" bagi Yayasan Matahati tersebut memiliki beberapa makna, di antaranya: sebagai pesan non verbal yang berisi makna harapan Yayasan Matahati dalam menurunkan prevalensi angka HIV AIDS di kabupaten Pangandaran; makna motivasi bagi para penyandang HIV AIDS agar berupaya untuk sampai pada "ZERO" HIV AIDS, yang berarti sembuh; dan makna persuasi bagi masyarakat untuk bersama-sama dalam rangka mencapai “ZERO” HIV AIDS di kabupaten Pangandaran. 
Berdasarkan hasil penelitian yang telah dilakukan, penulis juga memberikan saran terkait perlu adanya sinergitas yang positif dan berkelanjutan antara berbagai pihak khususnya dalam meminimalisir angka HIV AIDS. Sebagaimana simbol ZERO yang diusung oleh Matahati, maka hal tersebut dapat dijadikan sebagai bentuk sinergitas antara pemerintah, lembaga LSM, dan masyarakat di kabupatan Pangandaran.

\section{Ucapan Terima Kasih}

Dengan terbitnya artikel ini, penulis juga ingin mengucapkan terimakasih kepada Rektor dan pihak DRPM Universitas Padjadjaran yang telah membantu mendanai hibah penelitian program Hibah Internal Unpad (HIU). Program HIU tersebut yang telah mewujudkan terlaksananya penelitian ini di Pangandaran. Selain itu, penulis juga mengucapkan terimakasih setulusnya kepada pihak yayasan Matahati yang telah memberikan berbagai bantuan kepada penulis dalam terlaksananya program penelitian ini.

\section{Daftar Pustaka}

Ariadne, E. (2017). Konstruksi Makna Kandidat Politik Dalam Pemilu Kepala Daerah Bagi Masyarakat Kota Bandung (Perspektif Komunikasi Politik). Jurnal Komunikasi Universitas Tarumanagara, 9(2).

Arifin, H. S., Prasanti, D., \& Fuady, I. (2018). Komunikasi Sosial dalam Mendorong Penetapan Kebijakan Publik HIV/AIDS. Jurnal Ilmu Komunikasi UAJY, 15(2), 203.

Brouwer, D. (1998). The precarious visibility politics of self-stigmatization: The case of HIV/AIDS tattoos. Text and Performance Quarterly, 18(2), 114136.

Den. (2018). Perda HIV AIDS Sangat Mendesak di Kabupaten Pangandaran. Retrieved from www.radartasikmalaya.com website: https://www.radartasikmalaya.com/perda-hiv-aids-sangat-mendesak-dikabupaten-pangandaran/

Enceng. (2018). Dari 72 Penderita HIV AIDS di Pangandaran, hanya 34 orang yang Jangkau Layanan ARV. Retrieved from Harapan Rakyat website: https://www.harapanrakyat.com/2018/11/dari-72-penderita-hiv-aids-dipangandaran-hanya-34-orang-yang-jangkau-layanan-arv/

Iqbal, Z., \& Zorn, C. (2010). Violent conflict and the spread of HIV/AIDS in Africa. The Journal of Politics., 72(1), 149-162.

Madlani. (2018). HIV/AIDS Masuk Populasi Rendah, Yayasan Matahati Pangandaran Desak Perda Terbit. Retrieved from www.harapanrakyat.com website: https://www.harapanrakyat.com/2018/05/hiv-aids-masuk-populasirendah-yayasan-matahati-pangandaran-desak-perda-terbit/

Mahendra, G. K., \& Sugiantoro, H. A. (2018). MANAJEMEN PELAYANAN PENANGGULANGAN KASUS HIV-AIDS DI KOTA YOGYAKARTA. The Indonesian Journal of Public Administration (IJPA), 4(1)., 4(1). 
Ditha Prasanti, Hadi Suprapto Arifin, Ikhsan Fuady: Makna Simbol "ZERO” Sebagai Pesan Non Verbal Yayasan Matahati Dalam Mencegah Penyebaran HIV Aids Di Kawasan Pangandaran

Mukandavire, Z., Garira, W., \& Tchuenche, J. M. (2009). Modelling effects of public health educational campaigns on HIV/AIDS transmission dynamics. Applied Mathematical Modelling, 33(4), 2084-2095.

Mulyana, D. (2001). Metodologi Penelitian Kualitatif. Bandung: PT Remaja Rosdakarya.

Nzioka, C. (2010). The social meanings of death from HIV/AIDS: An African interpretative view. Culture, Health \& Sexuality, 2(1), 1-14.

Sugiyono. (2012). Metode Penelitian Kuantitatif Kualitatif dan R\&D. Bandung: Alfabeta. 